\title{
IMPLEMENTASI METODE ECRITURE CRÉATIVE BERBASIS BUDAYA LOKAL UNTUK MENINGKATKAN KETERAMPILAN MENULIS BAHASA PERANCIS LEVEL B1 DELF
}

\author{
Dadang Sunendar \\ Dwi Cahyani \\ Yadi Mulyadi \\ Departemen Pendidikan Bahasa Perancis FPBS UPI \\ Korespondensi: Jl. Dr. Setiabudhi No.229 Bandung 40154 \\ Pos-el: dadangsunendar@gmail.com
}

\begin{abstract}
Abstrak
Penelitian ini bertujuan untuk memperoleh data perihal:(1) model pembelajaran menulis bahasa Perancis yang sesuai dengan tuntutan kompetensi menulis bahasa Perancis level B1 DELF CECRL yang dikembangkan dari implementasi metode Ecriture créative berbasis budaya lokal, dan (2) penerapan metode écriture créative dalam pembelajaran Production Ecrite $V$ (Menulis) terkait substansi materinya terhadap pemerolehan keterampilan menulis bahasa Perancis level B1 DELF. Metode penelitian yang digunakan yaitu metode Research and Development (R\&D) melalui langkah-langkah yang ditempuh di antaranya, yaitu: (1) studi pendahuluan; (2) perencanaan dan pengembangan model, dan; (3) validasi model. Merujuk pada hasil penelitian, diperoleh data hasil penelitian bahwa model yang telah disusun yaitu model Ecriture crérative basée sur la culture locale telah mampu membantu mahasiswa dalam meningkatkan penguasaan keterampilan menulis teks bahasa Perancis level B1 DELF dengan tingkat ketercapaiannya sebesar 63,33\%. Selain itu, hasil uji coba tes yang telah dilakukan menunjukkan bahwa model ini terbukti efektif dalam meningkatkan kualitas proses dan hasil pembelajaran keterampilan menulis mahasiswa semester $V$ pada mata kuliah Production Ecrite $V$.
\end{abstract}

Kata-kata kunci: DELF level B1, CECRL, metode écriture créative, budaya lokal.

\begin{abstract}
This study aims to obtain data on: (1) a learning model in French writing in accordance with the demands of French writing skills of level B1 DELF CECRL developed from the implementation of local culture-based écriture creative method; and (2) the application of the Ecriture créative model in writing course of Production Ecrite regarding the acquisition of French writing skills of intermediate level (B1) DELF. The research method used in this study was Research and Development (R\& D) through: (1) preliminary studies, (2) planning and development models, and (3) validation of the model. Results indicate the local culture-based écriture créative model is able to help students improve their writing skills to the B1 DELF level with the rate of achievement of $63.33 \%$. Based on the results, it can be said that this model proved effective in improving the learning process of students' writing skills in the course of Production Ecrite $V$.
\end{abstract}

Keywords: B1 DELF level, CECRL, Ecriture créative method, local culture. 


\section{PENDAHULUAN}

Bahasa memiliki peran sentral dalam kehidupan manusia dan yang paling esensial adalah salah satu perannnya yaitu dalam membantu pengembangan intelektual, sosial, dan emosional manusia (dalam hal ini peserta didik) dan merupakan salah satu faktor penunjang dalam mencapai keberhasilan dalam mempelajari semua bidang studi.

Pembelajaran bahasa baik di tingkat sekolah menengah maupun di tingkat perguruan tinggi diharapkan tidak hanya pada penguasaan keterampilan berbahasanya tetapi juga dapat membantu peserta didik dalam mengenal dirinya, budayanya dan budaya orang lain. Selain itu, pembelajaran bahasa juga diharapkan dapat membantu peserta didik dalam memiliki motivasi dan mampu mengemukakan gagasan atau perasaan, berpartisipasi dalam masyarakat, bahkan dalam mengembangkan kemampuan analitis dan imajinatif dalam dirinya.

Melalui proses pembelajaran bahasa pula para peserta didik diharapkan memiliki kemampuanberkomunikasi di antaranya kemampuan berwacana (discourse competence) yakni kemampuan dalam memahami dan menghasilkan teks lisan atau teks tulis yang direalisasikan dalam keempat keterampilam berbahasa yaitu menyimak (compréhension orale), berbicara (production orale), membaca (compréhension écrite), dan menulis (production écrite).

Salah satu keterampilan berbahasa yang dianggap paling sulituntuk dikuasai menurut beberapa sumber adalah keterampilan menulis. Jika dalam bahasa lisan kesalahan berbahasa masih dapat ditolerir selama lawan bicara (interlocuteur) dapat memahami pesan pembicara, maka berbeda halnya dengan bahasa tulis. Dalam bahasa tulis, pesan harus disampaikan dengan baik dan koheren dengan tata bahasa yang benar.
Hal ini penting untuk dilakukan agar kesalahpahaman dapat diminimalisir dan pesan yang terkandung dalam tulisan tersebut dapat tersampaikan dengan baik.

Banyak kasus yang telah peneliti temukan dalam pembelajaran bahasa asing, dalam hal ini bahasa Perancis, di antaranya beberapa pembelajar bahasa Perancis memiliki keterampilan berbicara yang baik, namun tidak begitu baik dalam menulis. Keterbatasan ini tercermin dari beberapa kesalahan pada hasil tulisan bahasa Perancis mahasiswa seperti dalam hal ortograf, struktur kalimat/ tata bahasa, struktur teks, pemilihan kata/ diksi,dan koherensi. Bahkan kesalahan ortograf dapat dilakukan oleh beberapa penutur asli baik penutur bahasa Inggris ataupun penutur bahasa Perancis (locuteur natif d'anglais ou de français).

Hal tersebut di atas menunjukkan bahwa akuisisi dan penguasaan keterampilan menulis itu tidak mudah. Contoh lain yang menunjukkan kesulitan tersebut adalah dalam hal strategi menulis (stratégie d'écriture). Hal ini sebetulnya penting untuk diperhatikan oleh penulis ketika membuat sebuah tulisan agar dapat menarik para pembaca untuk berminat membaca hasil tulisannya. Pemilihan kata, perumusan ide, pengembangan ide, dan hal lainnya yang berhubungan dengan strategi menulis harus disusun dengan cermat agar dapat menghasilkan sebuah tulisan yang baik.

Pada Departemen Pendidikan Bahasa Perancis FPBS UPI, sesuai dengan kurikulum 2006, pembelajaran keterampilan menulis ini diberikan pada mata kuliah Production Écrite yang terbagi ke dalam enam tingkatan, yaitu Production Écrite I s/d VI (dari semester I hingga semester VI). Tentunya sasaran ketercapaian dan tingkat kesulitan dari setiap tingkat ini berbeda. Tujuan utama dari mata kuliah keahlian bidang studi tersebut adalah untuk mempersiapkan 
mahasiswa agar memiliki kemampuan menulis setara tingkat A1, A2, B1, dan B2 sesuai dengan standar kemampuan berbahasa Perancis DELF (Diplome d'Etudes de la Langue Française) pada kerangka acuan bahasa-bahasa Eropa yaitu CECRL (Cadre Européen commun de Référence pour les Langues). Materi yang diulas pada mata kuliah $P E I s / d P E V I$ di antaranya tema-tema yang terkait dengan kehidupan keseharian frankofon di antaranya saling bertukar informasi, pengalaman, pendapat, yang selanjutnya akan membentuk proyek kerja berupa penuangan gagasan dan pikiran secara tertulis dalam bentuk wacana deskriptif, naratif dan argumentatif dalam bahasa Perancis (genre-based writing) hingga menulis teks akademik (academic writing) seperti menulis résumé, compte-rendu, synthèse, dan dissertations sesuai dengan kaidah penulisan.

Sekaitan dengan kendala-kendala yang sering ditemui berdasarkan hasil-hasil penelitian sebelumnya dalam pembelajaran Production Écrite ini,diperlukan upaya penerapan metode pembelajaran yang mengarah pada upaya pemecahan masalah mahasiswa dan peningkatan kualitas proses pembelajarannya di antaranya dalam hal pemerolehan ide tulisan, pengembangan ide tulisan, pengembangan paragraf, analisis sistem ortograf bahasa Perancis pada hasil tulisan, konjugasi verba Perancis, pengenalan skema dan dokumen otentik berupa hasil tulisan (deskripsitif, naratif, argumentatif) versi Perancis dan Indonesia.

Merujuk pada data hasil penelitian terdahulu yang tertera pada roadmap penelitian bidang kajian pengajaran bahasa, diperlukan suatu tindak lanjut dalam upaya untuk meningkatkan kualitas pembelajaran menulis dalam mata kuliah Production Ecrite. Sebagai tahap pengembangan penelitian, sesuai dengan target capaian penelitian yaitu keterampilan menulis bahasa Perancis tingkat menengah (B1) DELF CECRL pada mata kuliah Production EcriteV (Keterampilan Menulis V), maka pada tahun ini tim peneliti akan melakukan penelitian pada mata kuliah Production EcriteVuntuk mahasiswa semester V tahun akademik 2013/2014 melalui tahapan penelitian berupa identifikasi jenis-jenis teks bahasa Perancis sesuai genre-nya dan sekaligus menerapkan metode Ecriture créative berbasis budaya lokal dalam menulis teks berbahasa Perancis tingkat menengah yaitu B1 DELF CECRL. Penggunaan metode Ecriture créative berbasis budaya lokal dalam penelitian ini didasarkan pada teori Michèle Sigal (2010) dan Sophie Moirand (2001) bahwa metode ini dapat membantu pembelajar dalam hal ini mahasiswa dalam menyajikan tulisan imajinatif seperti puisi, novel, roman, cerita pendek, drama, dan jenis teks lainnya melalui beberapa tahapan pembelajaran beserta unsur-unsur pendukung lainnya di antaranya media teks budaya lokal sebagai objek inspiratif (le déclencheur). Penerapan metode Ecriture créative dalam pembelajaran menulis bahasa Perancis dengan menambahkan unsur budaya lokal sebagai dokumen otentik pendukung pembelajaran diharapkan akan lebih mampu untuk menstimulus dan mengarahkan mahasiswa dalam pemerolehan keterampilan menulis bahasa Perancis tingkat menengah (B1) DELF CECRL dan sekaligus pemahaman budaya lokal dan budaya bahasa sasaran.

$\begin{array}{llr} & \text { Pada dasarnya keterampilan } \\ \text { menulis dalam } & \text { FLE } & \text { merupakan }\end{array}$ keterampilan yang yang dimiliki setelah keterampilan membaca. Membaca seringkali dikatakan sebagai keterampilan berbahasa yang pasif. Nunan (1999) mengatakan bahwa dalam pemerolehan bahasa kedua banyak orang yang menganggap bahwa membaca dan 
menyimak merupakan keterampilan kedua setelah berbicara dan menulis. Akan tetapi ia mengutarakan bahwa pada kenyataannya untuk menghasilkan suatu tulisan dan suatu bahan pembicaraan terlebih dahulu diperlukan membaca.

Sekaitan dengan hal di atas, Desmons (2005:46) menyatakan bahwa terdapat beberapa hal yang harus diperhatikan manakala akan membuat sebuah tulisan dalam bahasa Perancis, di antaranya adalah :

a. Pengorganisasian sistem tata tulis (keterbacaan tulisan, ortograf, tanda baca, tipografi) [L'organisation rigoureuse des signes graphiques (écriture lisible, orthographe, ponctuation, typographie)] ;

b. Kejelasan pesan (kosa kata yang tepat, sintaksis, efektivitas kalimat), [La clarté $d u$ message (précision $d u$ vocabulaire, correction de la syntaxe, concision)];

c. Penyusunan wacana yang utuh (kalimat majemuk, kata penghubung yanng tepat, kohesi tekstual). [L'élaboration d'un discours en continu (phrases complexes, liens logiques, cohésion textuelle)].

Dengan kata lain, kaidah tata tulis dan kaidah tata bahasa, morfologi dan sintaksis, serta kosa kata merupakan hal penting yang harus dikuasai seseorang untuk menulis sebuah teks. Lebih jauh lagi, Hardini (2006 :55) memaparkan pentingnya komponen-komponen pendukung dalam sebuah karangan, antara lain:

a. Ejaan yang mencakup huruf, penulisan kata dan tanda baca.

b. Kata dan makna, yang mencakup kata, ungkapan, istilah berikut ragam maknanya (leksikal, struktural, denotatif, konotatif, pergeseran makna).

c. Struktur kata, yang mencakup masalah bentuk-bentuk kata dan jenis-jenis kata. Perubahan bentuk kata akan menimbulkan perubahan makna,

d. Struktur kalimat, yang mencakup masalah penyusunan kalimat menurut bentuk, jenis, dan lain-lain. e. Struktur paragraf, yang mencakup komposisi sebuah paragraf, ragam paragraff, dan pertautan antar-paragraf.

f. Gaya bahasa, yaitu cara seseorang menggunakan bahasa serta memperindahnya.

g. Ragam bahasa, yaitu corak bahasa yang dipakai dilihat dari segi-segi tertentu. Misalnya ada ragam baku dan tidak baku, lisan dan tulisa, sastra dan ilmiah, dan sebagainya.

Oleh karena itu, jelaslah bahwa menulis merupakan sebuah kegiatan yang kompleks dan menghadirkan beberapa kesulitan tersendiri. Untuk dapat menguasai keterampilan ini diperlukan latihan dan praktek yang banyak dan teratur.

Kesulitan yang mungkin ditemukan ketika menulis teks dalam bahasa ibu dan bahasa asing tentulah berbeda. Wolff dalam Mangenot (2007) telah mengkelaskan kesulitan-kesulitan menulis teks dalam bahasa asing ke dalam tiga kelompok besar yaitu : kesulitan kebahasaan, terutama dalam hal leksikal; strategi menulis dalam bahasa asing; dan kesulitan sosiokultural.

Sekaitan dengan target capaian kompetensi kebahasaan, Kerangka acuan umum untuk bahasa-bahasa di Eropa (dalam bahasa Perancis: Cadre Européen Commun de Référence pour les langues) telah menetapkan standarisasi dalam hal tingkatan pembelajaran bahasa-bahasa Eropa yang dipelajari di negara-negara lain. Untuk itu, Dewan Eropa mengeluarkan Diploma Bahasa untuk beberapa bahasa Eropa di antaranya bahasa Perancis, Jerman, Inggris, Spanyol, Italia, dan bahasa Eropa lainnya yang memiliki standar tingkatan atau jenjang kelulusan yang sama. Dengan diploma ini maka akan tercipta keseragaman indikator tingkat kemampuan seseorang yang mempelajari bahasa Eropa misalnya di Indonesia, di Cina atau di Amerika. Untuk bahasa 
Perancis, diploma ini dikenal dengan nama DELF-DALF (Diplôme d'Étude de la Langue Française - Diplôme Approfondie de la Langue Française).

Diploma ini lebih menekankan pada empat keterampilan berbahasa yaitu : mendengarkan, berbicara, membaca, dan menulis. Diploma ini terbagi ke dalam beberapa tingkatan, yaitu A1 (tingkat pengenalan atau dasar), A2 (tingkat survive), B1 (tingkat menengah/ mencukupi), B2 (tingkat mandiri atau lanjutan) untuk DELF dan $\mathrm{C} 1$ (tingkat otonom atau berpengalaman), $\mathrm{C} 2$ (tingkat mahir) untuk DALF.

Keterampilan menulis merupakan salah satu keterampilan berbahasa yang berujung pada suatu produk sebagai hasil pemikiran. Keterampilan tersebut tidaklah mudah untuk dikuasai mengingat terdapat berbagai faktor yang kerap menjadi kendala dalam proses pemerolehannya. Faktor-faktor yang kerap menjadi kendala di antaranya pemahaman terkait ortograf, struktur kalimat/ tata bahasa, struktur teks, pemilihan kata/ diksi,dan koherensi di dalam tulisan.

Pembelajaran menulis bahasa Perancis melalui metode Ecriture creative telah banyak diimplementasikan di negaranegara anglofon sedangkan di negaranegara frankofon masih terbatas publikasi hasil implementasinya. Metode pembelajaran ini lebih banyak menitikberatkan pada pemberian latihan menulis pada pembelajar untuk lebih banyak mengenal jenis teks dan melatih teknik menulis berupa pemodelan. Menurut Moirand (2001) prinsip dasar dari metode Ecriture creative en classe de FLE berlandaskan pada pendekatan pedagogis melalui tahapan berikut:

a) Keterampilan menulis yang dibahas didasarkan pada perspektif pendekatan komunikatif yang mengutamakan interaksi (l'interaction). Para pembelajar bekerja secara berkelompok dan berbagi pengalaman nyata atau imajinatif yang akan membantu mereka dalam penulisan teks sesuai pengetahuan dan kemampuan berbahasa yang dimiliki.

b) Kegiatan menulis terintegrasi dengan kegiatan lainnya yaitu kegiatan menyimak, berbicara, dan membaca untuk meciptakan sebuah konteks (le contexte) yang diperlukan dalam penulisan teks bahasa Perancis. Kegiatan-kegiatan ini bermuara pada pemerolehan pengetahuan kebahasaan (linguistik), sosiolinguistik, diskursif, sosiokultural. Selain itu, membantu juga dalam pemahaman terkait tujuan penguasaan gramatikal, leksikal, ragam bahasa, pengetahuan terhadap jenis teks, pengetahuan budaya dan masyarakat frankofon.

c) Untuk mengawalinya, digunakan media pendukung sebagai déclencheur visual atau pun audio berupa: gambar, film, klip video, teks sastra, rangkaian kata/ kalimat, dan media lainnya untuk membantu daya imajinatif pembelajar.

d) Media pendukung yang digunakan merupakan dokumen otentik yang akan mengarahkan pembelajar untuk melakukan kontak secara langsung melalui media tersebut dengan budaya frankofon melalui bahasa Perancis.

e) Para pembelajar saling membantu pada tahap membaca ulang teks hasil tulisan dan mengoreksinya (phase de relecture et de correction).

f) Pengajar memberikan banyak kesempatan pada pembelajar untuk berbicara baik dengannya maupun dengan sesama teman sekelompok yang dinamakan personne ressource.

g) Pembelajar bekerja secara otonom (baik secara individu maupun kelompok) dalam memperoleh informasi yang mereka butuhkan dengan cara berkonsultasi dengan kamus, internet, tata bahasa, pengajar, teman sekelas, dan lain-lain.

h) Teks hasil tulisan dibacakan dengan nyaring untuk dievaluasi secara 
bersama-sama dan selanjutnya direvisi untuk perbaikan.

Selanjutnya Moirand (2001) menjelaskan unsur-unsur pendukung dalam pelaksanaan pembelajaran menulis melalui metode Ecriture créative ini sebagai berikut :

a) Le support de travail servant de déclencheur de l'activité: texte littéraire, chanson, extrait de film, clip vidéo, photo, peinture, poème, etc. (Alat pendukung pembelajaran membantu untuk titik tolak kegiatan berupa teks sastra, lagu,cuplikan film, klip video, foto, lukisan, puisi, dll)

b) Le type d'activité: reconstruire un texte décomposé, le reformuler ou produire un tout nouveau texte avec une contrainte ou non. (Jenis kegiatan : merancang kembali sebuah teks terpisah/acak, menyusunnya kembali atau membuat teks utuh yang baru yang berlawanan.

c) Le genre de texte produit: poème, récit, lettre, télégramme, dialogue, interview, affiche publicitaire, histoire, roman, nouvelle, conte, critique de film, etc. (Jenis teks yang dihasilkan : puisi, cerpen, surat, telegram, dialog, interviu, iklan, sejarah, roman, novel, dongeng, kritik film, dll.)

d) La forme de regroupement des élèves pendant l'activité: travailleront-ils seuls ou en petits groupes?. (Pembagian kelompok selama kegiatan: apakah diperlukan bekerja secara mandiri atau kelompok ?)

e) Les objectifs pédagogiques visés: (Tujuan pembelajaran yang ditargetkan:)

\begin{tabular}{lll} 
objectifs & \multicolumn{2}{c}{ linguistiques } \\
fonctionnels & (p.ex. donner un \\
conseil, & décrire & un \\
personnage, exprimer ses & sentiments) \\
sebjectifs & \multicolumn{1}{c}{ linguistiques } \\
grammaticaux, lexicaux
\end{tabular}

- objectifs linguistiques stylistiques (savoir comment créer un effet d'ironie, d'humour, savoir créer une atmosphère dans un texte, etc.)

- objectifs sociolinguistiques (manier les régistres de langue)

- objectifs discursifs (connaître le fonctionnement des types de textes)

- objectifs socioculturels (connaître le mode de vie et la culture d'un autre pays)

- objectifs socio-affectifs

- objectifs d'apprentissage (apprendre à apprendre).

Sehubungan dengan unsur budaya lokal yang diintegrasikan dengan metode Ecriture créative yang diteliti, hal ini didasarkan pada pendapat seorang pakar pendidikan yaitu Sinaga (2010) yang menyatakan bahwa strategi pembelajaran dengan mengedepankan pendidikan berbasis budaya (budaya folklor) perlu dikembangkan di sekolah-sekolah, karena dinilai dapat memotivasi para pembelajar untuk belajar lebih aktif hingga memberikan nilai tambah dan positif baginya.

Selanjutnya ia menambahkan bahwa guru, dapat memanfaatkan folklor (nilai-nilai pendidikan leluhur) untuk membentuk sikap dan kepribadian siswa, sehingga siswa tumbuh dan berkembang dengan basis budayanya sendiri. Hal tersebut dilandasi oleh cara berpikir, persepsi dan bertindak seseorang dipengaruhi oleh budaya, lingkungan dan orang lain di sekitarnya. Dengan demikian pemanfaatan aspek-aspek budaya, yakni fakta, lingkungan budaya, sistem sosial, sistem budaya, dan sistem nilai budaya, sangat diperlukan dalam proses pembelajaran. Dengan pendekatan budaya, akan memungkinkan pembelajar 
menunjukkan minat yang kuat dalam pelajaran dan senang untuk belajar, sebab pemahaman para siswa tentang pelajaran itu bersumber dari akar budayanya sendiri.

Mengacu pada penjelasan di atas, dalam penelitian ini, peneliti mengintegrasikan metode pembelajaran yang diteliti dengan berbagai dokumen otentik berupa teks folklor Indonesia dan Perancis terkait budaya bahasa sasaran dan budaya pembelajar (budaya bahasa asal), dalam rangka meningkatkan penguasaan keterampilan menulis bahasa Perancis tingkat menengah (B1) DELF CECRL. Tujuan dari pelaksanaan penelitian ini adalah untuk memperoleh data mengenai:

1) Model pembelajaran menulis bahasa Perancis yang sesuai dengan tuntutan kompetensi menulis bahasa Perancis tingkat menengah (B1) DELF CECRL yang dikembangkan melaluiimplementasi metode Ecriture créative berbasis budaya lokal.

2) Penerapan metode Ecriture créative dalam pembelajaran Production Ecrite Vatau level B1 DELF terkait substansi materinya terhadappemerolehan keterampilan menulis bahasa Perancis tingkat menengah (B1) DELF CECRL.

\section{METODE}

Terkait permasalahan penelitian yang telah dirumuskan, untuk menjawabnya peneliti menggunakan pendekatan penelitian Research and Development (R\&D). Adapun langkahlangkah yang ditempuh dalam melaksanakan penelitian ini terdiri atas tiga tahap, yaitu : (1) Studi Pendahuluan, (2) Perencanaan dan Pengembangan Model dan (3) Validasi Model. Pada tahap pengujian model dilakukan dengan eksperimen, yaitu dengan cara membandingkan nilai sebelum pemberian treatment dans sesudah pemberian treatment pembelajaran. Berikut ini desain eksperimen before-after (Sugiyono, 2011).

$$
\mathrm{O}_{1} \times \mathrm{O}_{2}
$$

Ket: $\mathrm{O}_{1 \text { : Nilai sebelum treatment }}$ $\mathrm{O}_{2}$ : Nilai sesudah treatment $\mathrm{X}$ : Pelaksanaan treatment

\section{HASIL DAN PEMBAHASAN}

Sehubungan dengan tujuan penelitian yang pertama, peneliti telah melalui sejumlah proses perancangan model pembelajaran untuk keterampilan menulis bahasa Perancis yang sesuai dengan tuntutan kompetensi menulis bahasa Perancis tingkat menengah (B1) DELF CECRL yang dikembangkan melalui implementasi metode Ecriture créative berbasis budaya lokal melalui beberapa tahapan berikut:

a. Penilaian (assesment) kebutuhan akan materi yang berhubungan dengan keterampilan menulis bahasa Perancis yang sesuai dengan tuntutan kompetensi menulis bahasa Perancis tingkat menengah (B1) DELF CECRL yang diperoleh melalui tanya jawab antara dosen dan mahasiswa sebelum mengawali perkuliahan atau sebelum dilaksanakan proses penelitian. Melalui tanya jawab tersebut, diketahui bahwa banyak mahasiswa yang terkendala dengan kepemilikan keterampilan menulis khususnya menulis teks naratif dan argumentatif sesuai level tersebut. Kesulitan tersebut ditengarai karena tuntutan menulis pada level B1 lebih cenderung pada pemofukasan pada kompetensi gramatikal yang 
lebih tinggi dibanding A2, begitu pula dengan penyajian tulisan yang memerlukan kosakata beragam dan keterkaitan antarparagraf yang dihubungkan dengan connecteurs logiques (kata penghubung antarparagraf yang relevan/logis)

b. Pokok bahasan dan jenis tugas berupa tes yang diberikan dalam pengajaran dipilih dan ditetapkan oleh peneliti untuk selanjutnya dirumuskan dalam indikator pencapaian tujuan pengajarannya.

c. Publik yang menjadi sasaran pembelajaran yaitu mahasiswa semester V Departemen Pendidikan Bahasa Perancis FPBS UPI yang tengah mengontrak mata kuliah Production Ecrite $V$ (Keterampilan Menulis V).

d. Bahan pelajaran dan rincian materi yang berkaitan dengan pencapaian tujuan umum pengajaran telah diidentifikasi dan dianalisis berupa materi yang diberikan pada mahasiswa berupa hand out.

e. Tujuan belajar yang harus dicapai oleh mahasiswa dirumuskan dan disesuaikan dengan isi/materi pelajaran dan/atau rincian tugas.

f. Rancangan kegiatan pembelajaran untuk mencapai tujuan belajar digambarkan dalam skenario pembelajaran.

g. Alat-alat bantu untuk mendukung kegiatan pembelajaran yang digunakan adalah materi tayangan (slides power point), LCD, dan bahan ajarotentik (documents authentiques).

h. Fasilitas lain yang digunakan adalah jaringan internet di FPBS untuk mengunduh dan menampilkan materi yang berhubungan dengan teks bahasa Perancis online. i. Evaluasi proses dan hasil kegiatan pembelajaran diperoleh dari data hasil observasi peneliti dan nilai tes.

j. Pelaksanaan tes awal dan akhir bagi mahasiswa dilakukan untuk mengetahui pemahaman dan penguasaan bahan atau materi yang telah dipelajari.

Dalam mengumpulkan data yang diperlukan, peneliti telah melakukan tiga tahap yang diuraikan sebagai berikut:

\section{1) Studi Pendahuluan}

Pada tahap ini peneliti telah melakukan studi literatur dan studi lapangan. Studi literatur dilakukan untuk menemukan konsep-konsep atau landasan-landasan teori sekaitan permasalahan penelitian dan juga untuk mendapatkan gambaran dari hasil-hasil penelitian terdahulu. Terkait studi literatur, peneliti telah menentukan sejumlah buku dan materi hasil unduhan dari sejumlah laman berbahasa Perancis yang dijadikan rujukan dalam proses penelitian terutama untuk penyediaan bahan ajar untuk keterampilan menulis teks naratif level B1 DELF berupa kumpulan teks otentik budaya lokal Indonesia di antaranya jenis folklor (cerita rakyat) yang merupakan jenis teks naratif sesuai dengan ketentuan level B1 DELF yang diperoleh dari berbagai sumber di antaranya dari majalah anak-anak dan remaja di Indonesia yang akan dijadikan sebagai objek inspiratif (le déclencheur). Begitu pula untuk teks naratif budaya Perancis pun telah peneliti kumpulkan dan seleksi dari berbagai sumber di antaranya dari laman: http//www.mamyraconte.com. dan

http//www.contespourlesenfants.com. yang digunakan pada saat penerapan metode yang diteliti dalam pembelajaran menulis bahasa Perancis tingkat B1 DELF CECRL. Studi lapangan 
dilakukan untuk mengukur kebutuhan dalam rangka menghasilkan desain model pembelajaran menulis bahasa Perancisuntuk tingkat menengah (B1) DELF CECRL melalui implementasi metode Ecriture créative berbasis budaya lokal. Adapun instrumen penelitian yang disusun dalam tahap ini adalah tes keterampilan menulis bahasa Perancis tingkat menengah (B1) DELF dengan merujuk pada ketentuan acuan bahasa-bahasa Eropa yaitu CECRL(terlampir).

\section{2) Perencanaan dan Pengembangan Model}

Pada tahap ini, peneliti telah menyusun model pembelajaran disertai materipembelajaran menulis bahasa Perancis untuk tingkat menengah (B1) DELF. Desain ini dikembangkan oleh peneliti bekerjasama dengan para ahli atau praktisi yang sesuai dengan bidang keahliannya dalam rangka mendapatkan pertimbangan ahli (expert-judgment). Desain modelini telah diujicobakanpada mahasiswa semester V untukmemperoleh data terkait keterampilan menulis bahasa Perancis level B1 DELF dalam pembelajaran Production Ecrite V.

\section{3) Validasi Model}

Setelah melalui tahap uji coba, evaluasi dan penyempurnaan, model pembelajaran menulis bahasa Perancis untuk tingkat menengah (B1) DELF melalui metode Ecriture créative telah divalidasi melalui proses implementasi pembelajaran keterampilan menulis teks bahasa perancis level B1 untuk menguji kelayakannya dengan cara membandingkan hasil belajar penguasaan keterampilan menulis bahasa Perancis sebelum dan sesudah pemberian treatment. Pada tahap validasi model digunakan desain penelitian eksperimen before-after. (Sugiyono, 2011).

Untuk tahap implementasi, peneliti telah menerapkan model yang telah dihasilkan yaitu Ecriture creative basée de la culture locale pada saat pemberian treatment/ perlakuan pembelajaran pada bulan Oktober tahun 2013 di kelas Kelas A (kelas yang diteliti) dengan jumlah mahasiswa sebanyak 30 orang. Sebelum melakukan proses pembelajaran berupa treatment/perlakuan peneliti memberikan prates terlebih dahulu.

Mengacu pada hasil prates keterampilan menulis teks bahasa Perancis level B1 DELF mahasiswa semester V tahun akademik 2013/2014, diperoleh data bahwa terdapat 3 orang mahasiswa (10\%) memiliki tingkat keterampilan menulis sangat baik (A), 9 orang (30\%) memiliki nilai baik (B), 10 orang $(33,33 \%)$ memiliki nilai cukup (C), dan 8 orang $(26,67 \%)$ memiliki nilai kurang (D). Dengan merujuk data hasil prates tersebut dapat diperoleh informasi bahwa 12 orang mahasiswa (40\%) dari jumlah total mahasiswa di kelas A yaitu 30 orang berada pada tingkat "Sangat Baik dan Baik" yaitu pada rentang nilai 18,6 -24.5.

Setelah melalui tahapan pengujian instrumen berupa prates terhadap responden, selanjutnya peneliti melakukan treatment/ perlakuan. Dengan merujuk pada teori Moirand dan Sigal, berikut ini model pembelajaran yang telah disusun peneliti dan diimplementasikan yaitu model pembelajaranEcriture creative basée sur la culture localeyang berlandaskan pada pendekatan pedagogis melalui tahapan berikut:

a) Para pembelajar (mahasiswa) secara berkelompok bekerja dan berbagi pengalaman nyata atau imajinatif yang akan membantu mereka dalam penulisan teks sesuai pengetahuan dan kemampuan berbahasa yang dimiliki. Kemudian mereka 
menuliskan hasil diskusi kelompok dan berbagi pengalaman baca tersebut. Dalam tahap ini, kelompok mahasiswa tidak hanya menuliskan apa yang diperoleh tetapi juga melakukan kegiatan lainnya yaitu kegiatan menyimak, berbicara, dan membaca.

b) Kelompok mahasiswa membuat sebuah konteks (le contexte) yang diperlukan dalam penulisan teks bahasa Perancis. Mahasiswa diarahkan pada pemerolehan pengetahuan kebahasaan (linguistik), sosiolinguistik, diskursif, sosiokultural. Selain itu, mereka pun diarahkan untuk memahami tujuan penguasaan gramatikal, leksikal, ragam bahasa, pengetahuan terhadap jenis teks, pengetahuan budaya masyarakat Indonesia dan frankofon dalam rangka projek menulis teks naratif sesuai level B1 DELF.

c) Untuk mengawalinya, dalam penelitian ini, dosen/peneliti menggunakan media pendukung sebagai déclencheur visual berupateks sastra jenis folklor untuk membantu daya imajinatif mahasiswa.

d) Media pendukung yang digunakan merupakan dokumen otentik yang akan mengarahkan pembelajar untuk melakukan kontak secara langsung melalui media tersebut dengan budaya masyarakat indonesia dan frankofon.

e) Para pembelajar mulai menulis teks naratif. Kemudian setelah selesai kegiatan menulis teks tersebut, mereka saling membantu pada tahap membaca ulang teks hasil tulisan dan mengoreksinya (phase de relecture et de correction).

f) Dosen/Peneliti memberikan banyak kesempatan pada pembelajar untuk berbicara baik dengannya maupun dengan sesama teman sekelompok sebagaipersonne ressource.

g) Pembelajar bekerja secara otonom (baik secara individu maupun kelompok) dalam memperoleh informasi yang mereka butuhkan dengan cara berkonsultasi dengan kamus, internet, tata bahasa, pengajar, teman sekelas, dan lainlain.

h) Teks hasil tulisan dibacakan dengan nyaring untuk dievaluasi secara bersama-sama dan selanjutnya direvisi untuk perbaikan.

Setelah pemberian treatment/ perlakuan sebanyak 5 pertemuan di bulan Oktober dan November 2013, selanjutnya peneliti melakukan pascates keterampilan menulis teks bahasa Perancis level B1 DELF.

Merujuk pada data hasil pascates, diperoleh informasi bahwa terdapat 9 orang mahasiswa $(30 \%)$ memiliki tingkat keterampilan menulis sangat baik (A),10 orang $(33,33 \%)$ memiliki nilai baik (B), 11 orang $(36,67 \%)$ memperoleh nilai cukup (C), dan tidak ada mahasiswa yang memiliki nilai kurang (D). Dengan merujuk pada data hasil pascates tersebut dapat diperoleh informasi bahwa 19 orang mahasiswa (63.33\%) dari jumlah total mahasiswa di kelas yang diteliti yaitu 30 orang berada pada tingkat "Sangat Baik dan Baik" yaitu pada rentang nilai 18,6 24.5. Hal ini menunjukkan bahwa keterampilan menulis mahasiswa telah mengalami peningkatan dan model pembelajaran yang disusun terbukti efektif diterapkan dalam pembelajaran mata kuliah Production Ecrite $V$. Dengan hasil tersebut, maka dengan perolehan nilai tes Production Ecrite B1 DELF antara 18 - 25, mahasiswa dipastikan akan lulus salah satu mata uji pada tes DELF B1 yaitu tes keterampilan menulis level B1 (Production 
Ecrite niveau B1 DELF) akan tetapi untuk mahasiswa yang berada pada rentang nilai cukup harus lebih meningkatkan lagi kemampuannya.

Hasil penelitian di atas telah membuktikan beberapa hal di antaranya model pembelajaran yang telah disusun peneliti yaitu model pembelajaran Ecriture creative basée de la culture locale yang didasarkan pada teori Moirand dan Sigal dengan berlandaskan pada pendekatan pedagogis telah dapat membantu meningkatkan keterampilan menulis mahasiswa semester $\mathrm{V}$ dalam menulis teks naratif level B1 DELF. Adapun tahapan dari model pembelajaran tersebut adalah sebagai berikut:

a) Para pembelajar (mahasiswa) secara berkelompok bekerja dan berbagi pengalaman nyata atau imajinatif yang akan membantu mereka dalam penulisan teks sesuai pengetahuan dan kemampuan berbahasa yang dimiliki. Kemudian mereka menuliskan hasil diskusi kelompok dan berbagi pengalaman baca tersebut. Dalam tahap ini, kelompok mahasiswa tidak hanya menuliskan apa yang diperoleh tetapi juga melakukan kegiatan lainnya yaitu kegiatan menyimak, berbicara, dan membaca.

b) Kelompok mahasiswa membuat sebuah konteks (le contexte) yang diperlukan dalam penulisan teks bahasa Perancis. Mahasiswa diarahkan pada pemerolehan pengetahuan kebahasaan (linguistik), sosiolinguistik, diskursif, sosiokultural. Selain itu, mereka pun diarahkan untuk memahami tujuan penguasaan gramatikal, leksikal, ragam bahasa, pengetahuan terhadap jenis teks, pengetahuan budaya masyarakat Indonesia dan frankofon dalam rangka projek menulis teks naratif sesuai level B1 DELF.

c) Untuk mengawalinya, dalam penelitian ini, dosen/peneliti menggunakan media pendukung sebagai déclencheur visual berupateks sastra jenis folklor untuk membantu daya imajinatif mahasiswa.

d) Media pendukung yang digunakan merupakan dokumen otentik yang akan mengarahkan pembelajar untuk melakukan kontak secara langsung melalui media tersebut dengan budaya masyarakat indonesia dan frankofon.

e) Para pembelajar mulai menulis teks naratif. Kemudian setelah selesai kegiatan menulis teks tersebut, mereka saling membantu pada tahap membaca ulang teks hasil tulisan dan mengoreksinya (phase de relecture et de correction).

f) Dosen/Peneliti memberikan banyak kesempatan pada pembelajar untuk berbicara baik dengannya maupun dengan sesama teman sekelompok sebagai personne ressource.

g) Pembelajar bekerja secara otonom (baik secara individu maupun kelompok) dalam memperoleh informasi yang mereka butuhkan dengan cara berkonsultasi dengan kamus, internet, tata bahasa, pengajar, teman sekelas, dan lainlain.

h) Teks hasil tulisan dibacakan dengan nyaring untuk dievaluasi secara bersama-sama dan selanjutnya direvisi untuk perbaikan.

Setelah penerapan model yang diteliti yaitu model pembelajaran Ecriture Creative basée sur la culture locale dalam pembelajaran menulis teks naratif berbahasa Perancis level B1 DELF CECRL, peneliti menemukan sejumlah 
kelebihan dan kekurangan baik dari sisi proses maupun dari sisi persona peneliti sebagai pengajar dan mahasiswa sebagai pembelajar. Dari kedua sisi tersebut dapat diperoleh informasi kelebihan dari model tersebut yaitu: (1) para pembelajar (mahasiswa) dapat bekerja secara kolaboratif dan berkelompok sehingga mereka dapat saling berbagi pengalaman nyata atau imajinatif yang telah membantu mereka dalam penulisan teks sesuai pengetahuan dan kemampuan berbahasa yang dimiliki; (2) membantu mahasiswa dalam kegiatan pembelajaran lainnya yaitu tidak hanya menulis tetapi juga kegiatan menyimak, berbicara, dan membaca; (3) mahasiswa terbantu dalam pembuatan sebuah konteks (le contexte) yang diperlukan dalam penulisan teks bahasa Perancis sehingga mereka lebih diarahkan pada pemerolehan pengetahuan kebahasaan (linguistik), sosiolinguistik, diskursif, sosiokultural. Selain itu, mereka pun diarahkan untuk memahami tujuan penguasaan gramatikal, leksikal, ragam bahasa, pengetahuan terhadap jenis teks, pengetahuan budaya masyarakat Indonesia dan frankofon dalam rangka projek menulis teks naratif sesuai level B1 DELF; (4) adanya media pendukung sebagai déclencheur visual berupa teks sastra jenis folklor untuk membantu daya imajinatif mahasiswa yang dapat membantu mahasiswa dalam mengembangkan konsep pikiran terkait teks naratif; (5) media pendukung yang digunakan yaitu berupa dokumen otentik telah dapat mengarahkan mahasiswa dalam melakukan kontak secara langsung melalui media tersebut dengan budaya masyarakat lokal/ Indonesia dan frankofon; (6) Mahasiswa dilatih untuk saling membantu pada tahap membaca ulang teks hasil tulisan dan mengoreksinya (phase de relecture et de correction); (7) Peran dosen/peneliti tidaklah dominan melainkan sebagai fasilitator dalam proses diskusi antarsesama teman sekelompok mahsiswa, kelompok lainnya dan dengan dosen pengampu mata kuliah. Kegiatan ini dinamakan kegiatan personne ressource; (8) mahasiswa dilatih untuk bekerja secara otonom (baik secara individu maupun kelompok) dalam memperoleh informasi yang mereka butuhkan dengan cara berkonsultasi dengan kamus, internet, tata bahasa, pengajar, teman sekelas, dan lainlain; dan (9) adanya proses diskusi hasil teks yang telah ditulis dan dibacakan dengan nyaring untuk dievaluasi secara bersama-sama dan selanjutnya direvisi untuk perbaikan. Adapun kekurangan dari implementasi model ini adalah: (1) penguasaan tata bahasa Perancis mahasiswa kerap kali menjadi kendala saat mereka menulis teks naratif level B1 DELF; dan (2) penguasaan mahasiswa terkait koherensi teks yang dibuat (connecteurs logiques du texte) masih rendah sehingga perlu untuk diberikan beberapa solusi untuk mengingatkan penggunaannya saat menulis teks.

\section{SIMPULAN DAN SARAN}

Mengacu pada hasil penelitian yang telah dipaparkan di atas, peneliti menyimpulkan bahwa model yang telah disusun yaitu model Ecriture crérative basée sur la culture locale telah mampu membantu mahasiswa dalam penguasaan keterampilan menulis teks bahasa Perancis level B1 DELF meskipun tingkat ketercapaiannya sebesar 63,33\%. Namun jika dibandingkan dengan data nilai prates yaitu sebesar $40 \%$ maka dapat dikatakan bahwa model ini terbukti efektif dalam proses pembelajaran menulis mahasiswa semester V pada mata kuliah Production Ecrite $V$. Dengan mengacu pada kelebihan dan kekurangan di atas, peneliti menyarankan agar: (1) dalam pembelajaran menulis di tingkat yang lebih bawah yaitu pada keterampilan menulis level A1 dan A2 yaitu pada mata kuliah Production Ecrite I, II, III, dan IV, perlu kiranya 
mahasiswa dilatih dan diberikan materi terkait tata bahasa yang gradasinya lebih terarah ke level B1 dan tingkat koherensi teks yang dibuat (connecteurs logiques $d u$ texte) yang masih rendah sehingga perlu untuk diberikan beberapa latihan dalam mengamati, menganalisis dalam menghubungkan antarparagraf pada teks yang sudah jadi (documents authentiques).

\section{UCAPAN TERIMA KASIH}

Peneliti mengucapkan terima kasih kepada pihak-pihak yang telah membantu terlaksananya penelitian ini di antaranya kepada DP2M DIKTI dan LPPM UPI yang telah membantu dalam pendanaan penelitian ini. Begitu pula kepada Departemen Pendidikan Bahasa Perancis FPBS UPI yang telah memberikan izin dalam pengambilan data serta para mahasiswa semester $\mathrm{V}$ tahun akademik 2013/2014 yang mengontrak mata kuliah Production Ecrite $V$ sebagai responden penelitian.

\section{PUSTAKA RUJUKAN}

Desmons, F. et al. (2005). Enseigner le FLE : Pratiques de Classe. Paris: Guide Belin.

Hardini, T.I. (2006). Penilaian Kemampuan Menulis Mahasiswa Dengan Model Writtig Workshop Melalui Internet. Jurnal Bahasa \& Sastra,Vol. 7(2). ISSN: 1412-0712, hal.33-43.
Mangenot, F. (2007). Contexte et conditions pour une réelle production d'écrits en ALAO. Diakses dari laman: http://alsic.ustrasbg.fr/ Menus/framerec.htm (26 mai 2009).

Moirand, S. (2001). L'écriture créative en classe de français langue étrangère. Diakses dari laman: http://www.form-acom.org/article20d8.htmlarticle $=31$ (15 April 2012)

Nunan, D. (1999). Second Language Teaching and Learning.Boston, Massachusetts, USA: Heinle \& Heinle Publisher.

Sigal, M. (2010). Pratique d'écriture créative et activité de classe. Diakses dari laman: http://www.ciep.fr/formations/prati qued'ecriturecreativeetactivitedecl asse (4 mei 2011)

Sinaga, B. (2010). Pembelajaran berbasis budaya perlu dikembangkan dalam pendidikan. Pada laman : http://www.waspada.co.id/index.ph

p.-content\&viewarticlepembelajaran-berbasisbudaya-perlu-dikembangkan.htm. (26 mai 2012)

Sugiyono. (2011). Pendekatan Kualitatif, Kuantitatif dan $R \& D$. Bandung: Alfabeta.

http//www.mamyraconte.com. http//www.contespourlesenfants.com. 